\title{
A magyar szenior atlétika szervezödése és megbecsültsége
}

\section{Appreciation and organization of Hungarian master athletics}

\author{
Lisztóczki János¹, Benczenleitner Ottó², Béres Sándor² \\ 1 Babits Mihály Gimnázium, Budapest (Mihály Babits secondary school, Budapest) \\ 2 Magyar Testnevelési Egyetem, Atlétika tanszék (Hungarian University of Physical Education , Budapest)
}

\begin{abstract}
Absztrakt - A szenior atlétika világszerte növekvő népszerúségnek örvend. A nemzetközi veterán szövetségek által rendezett világversenyek rendre több ezer indulót vonzanak minden földrészen. Tanulmányunk egy a már hasonló témában íródott áttekintó cikk alapján (Béres, László, Hámori, Tóth, 2011), azt újabb kérdéskörökkel, anyagi szempontokra-, támogatottságra is vonatkozó kérdésekkel kiegészítve, több veterán atlétát megkérdezve, egy átfogóbb, friss képet hivatott közölni a mai magyar szenior atlétikáról. A 2014-es budapesti világbajnokságon és a 2016-os Ancona-ban rendezett fedett Európa Bajnokságon az egyes országok csapatai, mind létszámukat, felszerelésüket, mind felkészültségüket tekintve, jelentős eltéréseket mutattak. Több európai nemzet szenior atlétái, az imént említett, és egyéb szempontok alapján is igen komoly megbecsülésnek örvendenek. Mindezek mellett, ill. ezek ellenére a magyar szenior atlétika eredményei messze felülmúlják minden más korosztály eredményességét. Sajnos megbecsültségük hasonló mértékú, de ellentétes előjelú. Ezzel a háttérrel kutatásunk célja felmérni e sportolni vágyó réteg gondolkodás-módját, szokásait, eredményeit erkölcsi-, anyagi támogatottságát, és esetleges további lehetóségit.
\end{abstract}

Kulcsszavak: szenior, veterán, atlétika, MASZ, SZAMOSZ, kérdőív, helyzetelemzés

\begin{abstract}
Popularity of master athletics is increasing all over the world. The European and world competitions held and organised by international master associations from time to time attract more and more athletes on every continent. The study intends to give an overview about present day senior athletics - based on a previous survey (Béres, László, Hámori, Tóth, 2011) - completed with newer (financial and sponsoring) aspects. More subjects were interviewed to give information about the actual Hungarian master athletics. The World Master Athletics Championship held in Budapest in 2014 and the Indoor European Master Athletics Championship 2016 in Ancona showed significant differences in numbers, equipment's and preparation levels. Highly appreciated Master athletes from several nations participated. The performance of Hungarian senior athletes was beyond expectations and overruled the results of all other age category Hungarian athletes. Their appreciation is similar but with a negative sign. The aim of this investigation is to assess their way of thinking, habits, performance, the moral and financial support, and the future possibilities of this age group.
\end{abstract}

Keywords: senior, master, track \& field, MASZ, SZAMOSZ, questionnaire, situation analysis

\section{Irodalmi áttekintés}

A szenior atlétika magába foglalja mindazokat az atlétikára jellemző versenyformákat, szakágakat, melyek a Nemzetközi Atlétika Szövetség (IAAF) működésére, valamint a felnőtt korosztály versenyeire is jellemző. A szabályok megalkotásánál is a sportág vezető szervének ajánlásai voltak irányadóak. Rendeznek pálya versenyeket, országúti versenyeket, mezei futó versenyeket (cross country). Az atléták szenior korosztályban 35 éves kor felett indulhatnak, ötévenkénti 
korcsoport-bontásokban. Ha a versenykiírás másképp nem rendelkezik, az életkor mindig a verseny első napjára értendő a WMA szabálykönyv 141. szabálya alapján. Így előfordulhat, hogy a versenyző az előfutamot és a középdöntőt 44 évesen futja, de a döntőt már45 évesen. Természetesen a 40-45 évesek kategóriájában.

A világversenyekre történő nevezés és indulás nincs nevezési szinthez kötve. Bárki indulhat, aki megfelelö életkorban van, orvosilag alkalmas és a nevezési díjat befizette. Gyakori eset, hogy a versenyzőket elkísérő házastársak is kipróbálják magukat egy általuk választott számban.

\section{Szabályok}

Természetesen a szabályok is igazodnak az életkorból adódó képességszint csökkenéshez, pl. a rajtszabály szerint nem zárják ki a versenyzőt az első rossz rajtot követően. Gátfutásnál a gátak magassága és távolsága, valamint maga a lefutandó táv is igazodik a versenyzők életkorából adódó képességszint csökkenéshez. Akadályfutásnál a táv hoszsza és az akadályok magassága, valamint száma is változik. A dobószámokban a kor előrehaladtával csökken, csökkenhet a szerek súlya (vannak versenyzők, akik megmaradnak a hivatalos szereknél). Természetesen a saját szer használata - hitelesítés után - megengedett, de ebben az esetben bármely más vetélytárs is dobhat vele.

A távolba ugró számokban (távol, hármas) az elugró gerendát a homokgödörhöz közelebb festik, ill. festhetik fel a biztonságos beérkezés érdekében. A váltófutás speciális szenior szabálya, hogy a váltó csapat abban a korosztályban indulhat, ahová legfiatalabb tagja tartozik. Tehát idősebbek is indulhatnak a fiatalabbakkal egy csapatban. Gyakorlatias szabály, hogy nincs előnevezési lehetőség, csak helyszíni, mert a váltófutó csapat összeállításába könnyen beleszólhat sérülés, vagy más előre nem látható esemény. Győzni csak a legfelkészültebb csapat tud, mert nem elég gyorsan futni, fontos a váltások precíz végrehajtása is. A szabályokat a WMA a World Masters Athletics Assisiation alkotja az IAAF-el karöltve.

\section{Korszorzó}

A korszorzó egy praktikus adatbázis a különböző életkorú versenyzők teljesítményeinek összehasonlításához. Így versenyszámonként nemcsak korcsoportos, hanem abszolút eredményhirdetést is lehet tartani (Rehpenning, B., Harvey R., Beckers S., 2010). A korszorzó azt is megmutatja, hogyan lehet egy idősebb versenyző eredményét összevetni egy aktuális élversenyzőével. Bár 1991 óta folyamatosan javítják és frissítik az adatokat, egy-egy kiugróan magas szintú szenior eredmény az aktuális világcsúcsnál is nagyobb teljesítményt mutat! Például a jamaikai származású, ám szlovéniai színekben versenyző Marlene Ottey 2006-ban 46 évesen futott 100 méteren 11,34mp-et. Ez önmagában is kiemelkedő eredmény, hiszen jobb Szabó Enikő 2004-ben futott magyar csúcsánál is. A korszorzó táblázat adatai szerint ez 10,12mp-nek felel meg. Mivel a jelenlegi világrekordot női 100m-en Florence Grifith Joyner tartja 10,49mp-el 1988 óta, így kijelenthető, hogy Ottey átkonvertált eredménye irreális, noha teljesítményérték szempontjából magasabb szintú.

\section{Szövetségi rendszer}

A sportág legfelsőbb, nemzetközi irányító szerve az IAAF (International Association of Atbletics Federations). Elnöke: Lord Sebastian Coe. A Nemzetközi Atlétika Szövetséget 1912. július 17-én alapította meg Stockholmban 17 ország nemzeti atlétika szövetsége, akkori nevén a Nemzetközi Amatőr Atlétika Szövetséget. Az amatőr szót egészen 2001-ig tartotta meg nevében; akkori kongresszusán változtatták Nemzetközi Amatőr Atlétika Szövetség névre, hiszen az 1982-ben elfogadott szabályok lehetővé tették a sportolóknak, hogy pénzdijat fogadjanak el a versenyzésükért.

A veterán atlétika legmagasabb szintú szervezete a World Masters Atbletics, 2001-ig WAVA (World Association of Veteran Atbletics), melynek minden földrészen múködnek tagszervezetei. Elnöke az ausztrál Stan Perkins. Fő feladata a világversenyek szervezése, összehangolása. Szoros kapcsolatban áll az IAAF- fel, és az International Masters Games Association-nal. Az IMGA a NOB által elismert szervezet, mely támogatja az olimpiai mozgalmat, a ,sport for all” filozófiáját. Célja, hogy ösztönözzön minden embert, hogy a fiatal koron túl is folytassák a sportot, egész életükön át. Négyévente kerül megrendezésre a World Masters Games (Veterán Világjátékok), ahol a sportok királynője is jelen van. A Játékok népszerűségét jellemzi, hogy 2009-ben Sydney-ben 28 sportágban 95 ország szenior sportolói neveztek. Összesen 28676 fó versenyzett, ami duplája az ugyanitt rendezett 2000-es Olimpiai Játékokon indulóknak. 
Az Európai Szenior Atlétika Szövetség, az European Masters Atbletics (EMA) - korábbi nevén European Veteran Athletics Association (EVAA) -, az öreg kontinensen szervezi és irányítja a szenior Európa Bajnokságokat. Magyarországon az 1897-ben alakult Magyar Atlétika Szövetség, ezen belül a nemrég választott Szenior Bizottság irányítja a szenior atlétika mozgalmat.

A sportról szóló 2004. évi I. törvény alapján a bizottság szervezi a szenior atlétika mozgalmát, kialakítja a szenior versenynaptárt, segíti a nemzetközi versenyeken való részvételt, működteti a válogatott keretet, képviseli a szenior atléták érdekeit a szövetségben illetve a nemzetközi sportéletben.

2005 év elején megalakult a Szenior Atléták Magyarországi Szövetsége (SZAMOSZ), amely a MASZ jogi személyiséggel felruházott szervezeti egysége, azaz alszövetsége volt. 2014-ben a MASZ ezt megszüntette, s a továbbiakban mint szakbizottság működteti.

\section{Történeti áttekintés}

Korábban a középkorú sportolók Európában, Ausztráliában és USA-ban a fiatal élversenyzők között indultak, föleg az országúti és terepfutó versenyeken, de ügyességi számokban is értek el kiemelkedő eredményt 40 éven felüliek.

1966-ban egy San Diegó-i ügyvéd, David Pain szervezésében jött létre az első amerikai veterán atlétika verseny, az úgynevezett „Masters Miles”. Szabadtéri és fedett pályás versenyeket egyaránt rendeztek, 40 éves és annál idősebb indulóknak. Társaival hamarosan elindította az USA szenior bajokságát az Amatőr Atlétika Unió (AUU) égisze alatt, ahol 40 év volt a korhatár. A versenyt a San Diegó-i Balboa Stadionban tartották 1968. július 19-20-án, 168 indulóval. 1969-ben már 200-ra nőtt a résztvevők száma, ekkor vezették be a 10 évenkénti korosztályos kategóriákat. Az USA-ban és Kanadában a mozgalom népszerüsége folyamatosan nőtt, számos Masters Klubot hoztak létre.

Ezzel egy időben, Európában is megrendezték az első hivatalos versenyeiket a frissen alakult szervezetek. Németországban 1968-ban jött létre az Interessen-Gemeinschaft Alterer Langstreckenlaufer (IGAL), Nagy- Britanniában pedig a British Veteran Athletic Club. 1971-ben Pain és felesége Londonba utaztak, hogy egyeztessenek az európai szervezetekkel egy leendő nemzetközi szenior versenysorozatról. 1972-ben az Egyesült Államok és Kanada
152 főből álló szenior atlétika válogatottja európai versenytúrán vett részt. Előbb London, Helsinki, Stockholm, Göteborg volt a találkozó helyszíne, majd Németországban, a Müncheni Olimpia rendezésének idején, Kölnben szerepeltek. 1973 decemberében Pain51 sportolóval túrázott a Csendes-óceán déli részén és Óceániában. Ezek voltak az első hivatalosan szervezett nemzetközi válogatott viadalok.

Dél-Amerikában az egykori chilei tízpróbázó Hernán Figureoa Burg kezdeményezte az országa szenior atlétika szervezetének (ASECHI) létrehozását, amely 1978. október 15-én alakult meg, majd 1979. december 15-én Buenos Airesben a DélAmerikai Szenior Atlétikai Szövetséget alapították meg öt ország képviselői révén, és lebonyolították az első kontinensviadalt is.

Az első Szenior Atlétika Világbajnokságot 1975. augusztus 11-16 között rendezték Torontóban, 32 nemzet részvételével. Mivel szükségessé vált egy sportágat irányító testület, az országok képviselői a Torontói Egyetemen üléseztek és választottak egy bizottságot, melynek feladata egy világszervezet létrehozása volt.

A World Association of Veteran Athletes (WAVA) 1977. augusztus 9-én Göteborgban jött létre, ahol a második Szenior Atlétika Világbajnokságot is rendezték. Később megváltoztatták a szervezet nevét World Masters Atletics-re (WMA), bevezették az öt évenkénti korosztályokat mindkét nemnél 35 évtől kezdődően. Azóta kétévente rendeztek szabadtéri világbajnokságot, egészen 2015-ig (Lyon). 2011 júliusában megváltoztatták az alapszabályt, hogy 2016-tól (Perth) kezdődően páros években legyenek a VB-k. Azért volt erre szükség, hogy összehangolják a négyévente rendezett Masters Games-szel, ami egy sok sportágat átölelő multi-sport esemény. Mondhatnánk: Veterán Olimpia [10].

\section{Magyar sikerek a Világbajnokságokon}

Az eddigi legsikeresebb szereplés a 2014-es rendezésű budapesti Fedett-pályás Világbajnokságon történt. A hazai rendezés óriási mozgósító erővel bírt: a versenyre 320 magyar atléta készült fel és lépett pályára. Egy ilyen remek lehetőséget a szenior mozgalom egyetlen sportolója sem akarta kihagyni, így még azok is felhúzták a nyúlcipőt, akik korábban csak játszottak a versenyzés gondolatával. Voltak, akik fiatal korukban más sportágban jeleskedtek, ám a világbajnokságon való indulás miatt 
veteránként az atlétikát választották.

A négy helyszínen megrendezett látványos sportesemény nagy népszerüségnek örvendett, jó hangulatban zajlottak a versenyek. Egyedülálló megoldást jelentett a két közvetlenül egymás melletti fedett atlétika csarnok, ahol - amellett, hogy volt megfelelő számú ugró és dobó helyszín -, a bemelegítést is jó körülmények között lehetett végezni. A két Syma csarnokban elfért minden, ami a 4000 sportolót és kísérőiket kiszolgálni hivatott: öltözők, jelentkeztető hely, eredményhirdető terem, étterem, ajándékárusítás, közösségi tér, és természetesen a következő évek világversenyeiről sok-sok információ: térképek, videók, szállás lehetőségek, stb. A szabadtéri dobószámokat a néhány perces sétával elérhető „dobó fészernél” bonyolították le. Külső bemelegítő helyszínként a KSI pályát és a csarnok melletti salak futókört egyaránt igénybe lehetett venni. A különös hangulatú szoborpark szocreál stílusú alkotásai az ötvenes évekre emlékeztették a szeniorokat, ugyanis azóta állnak eredeti helyükön. $\mathrm{Az}$ eredeti elképzelés szerint az olimpián győztes sportolók itt vonultak volna a kapuhoz és be a teltházas Népstadionba. A negyedik helyszín a Városliget, ahol a gyaloglás, cross-country, és a félmaraton versenyszámok kerültek megrendezésre (Turcziné, 2014).

Budapestre 70 országból 4000 szenior sportoló érkezett, a legnépesebb csapattal - 516 indulóval - Németország érkezett. A különböző korcsoportokban több mint 2200 érem talált gazdára; a 22 versenyszámban 709 aranyérem került kiosztásra. $\mathrm{Az}$ érmek mellett ugyanolyan hangsúlyt érdemel az összes résztvevő segítségével hat napon át tartó sportági varázs, az atlétika kortalan szépsége, a mozgás életkorokon átívelő nagyszerüsége. A korelnök versenyző a 98 éves Giuseppe Ottaviani volt, aki 9 számban jelezte indulási szándékát. A VB egyik sztárja minden kétséget kizáróan a kanadai Olga Kotelko volt, aki a 95-99 korosztályban egyedüli indulóként versenyezett, mégpedig összesen 11 versenyszámban. A 95 esztendősen is rendkívüli erőnléttel rendelkező hölgy megjavította az általa tartott magasugró világcsúcsot $(76$ cm-ről 78 cm-re). Több szenior sportolóhoz hasonlóan Olga Kotelko is idősebb korában talált rá az atlétikára. Ukrán emigránsok 11 gyermeke közül a hetedikként jött világra 1919. március 2-án Kanadában. Fiatal korában nem volt profi sportoló, amatőr szinten softballozott. Tanárként dolgozott, majd 1984-ben ismét a softball bűvöletébe került. 77 évesen indult életében elöször atlétika versenyen Arizonában és a gerelyhajítás hatodik sorozatában megjavította az aktuális korosztályos világrekordot. Jelenleg 27 világcsúcsot mondhat magáénak a napi több órát sportoló Olga, aki szerint:" mindenkinek tudnia kell, hogy csak egy teste és egészsége van, felelősséggel tartozik érte" (Juha, 2014).

A hazai közönség előtt rekord számú, azaz 320 magyar atléta lépett pályára, akik kiemelkedő teljesítményükkel ragadtatták tapsra a nézőket. Világbajnoki szereplésük minden dicséretet megérdemel. A magyar atléták összesen 56 érmet szereztek, a Világbajnokság 6 napja alatt 19-szer csendülhetett fel a himnusz. A 19 aranyérem mellett 21 ezüst,- illetve 16 bronz a dobogós mérleg. A magyar csapat az érmes pozíciók mellett nagyon sok 4-8. helyezéssel is büszkélkedhet, „a hazai pálya kötelez” szellemében mindenki legjobb tudása szerint versenyzett (Turcziné, 2014).

\section{Hipotézis}

Feltételezésünk szerint a kérdőívek segítségével átfogó képet kaphatunk az eredményes nemzetközi szereplés okairól, a magyar szenior atlétika jelenlegi helyzetéről, a felkészülés hátteréről, pillanatnyi állapotáról.

Feltételezzük, hogy a master atlétákat versenyzésük anyagilag jelentősen megterheli, mégis amatőr szemlélettel, a központi támogatás hiánya ellenére - erős motivációjuk okán - kiemelkedően, mondhatnánk aránytalanul sokat áldoznak sportolási szokásaikra.

Feltételezésünk szerint az eredményesség nem mutat szoros összefüggést az edző személyével.

Feltételezzük továbbá, hogy az edzések gyakorisága, az edzéskörülmények és az eredményesség között összefüggés található 35 éves kor felett is.

\section{Módszerek}

A téma vizsgálatára a kérdőíves módszert alkalmaztunk, mely 3 részre tagolódik:

- szenior kor előtti sportolási szokások;

- szenior évek;

- szenior atléták sportgazdaságot érintő pénzügyi szokásai és erkölcsi támogatottsága.

\section{Vizsgálat helye, ideje}

A kérdőivet a 2016-os perth-i világbajnoksággal 
egy időben tettük közzé a világhálón.

\section{Vizsgálati személyek}

A Szenior Atléták közösségi csoportjában meghirdetett kérdőívet 65 fö töltötte ki, 26 nő és 39 férfi. A legfiatalabb korosztály a 35-39, a legidősebb a 7579-es korcsoportbs tartozott. Életkori átlaguk 51,9 év volt.

Lakóhely szerint 31 különböző településen élnek a válaszadók: legtöbben, 28-an Budapesten, 36 fö vidéki városban, valamint 1 fo Erdélyben.

\section{Eredmények}

Versenyszámok, melyekben a szenior atléták érdekeltek
Milyen versenyszámokban szoktál indulni? (több válasz lehetséges)

Egy versenyző több versenyszámot is megjelölhetett, az ezekben való indulás szerint. A 65 válaszadó összesen 199 versenyszámban szokott indulni, ez átlagosan 3 számot jelent.

A 65 válaszadó atléta bejelölései alapján 94 futószám érdekeltséget összesítettünk, melyből 56 sprint és gát, 22 középtáv, 16 hosszútáv és gyaloglás. Az ugró szakágban 41, a dobó szakágban 54, az összetett szakágban 6 jelölés érkezett. Legnépszerübbnek a $100 \mathrm{~m}$ és a súlylökés bizonyult, a $3000 \mathrm{~m}$ akadályt senki sem választotta (noha tudjuk, hogy a világbajnokságon ezüstérmet szerzett Jacsó István).

1. táblázat $A$ magyar szenior atléták ( $n=65)$ által érdekelt versenyszámok

\begin{tabular}{|c|c|c|}
\hline $100 \mathrm{~m} / 60 \mathrm{~m}$ & 21 & $10,6 \%$ \\
\hline $200 \mathrm{~m}$ & 18 & $9 \%$ \\
\hline $400 \mathrm{~m}$ & 10 & $5 \%$ \\
\hline $800 \mathrm{~m}$ & 12 & $6 \%$ \\
\hline $1500 \mathrm{~m}$ & 12 & $6 \%$ \\
\hline $5000 \mathrm{~m}$ & 8 & $4 \%$ \\
\hline $10000 \mathrm{~m}$ & 4 & $2 \%$ \\
\hline maraton futás & 4 & $2 \%$ \\
\hline $100 \mathrm{~m}$ gát $/ 110 \mathrm{~m}$ gát & 6 & $1 \quad 3 \%$ \\
\hline $400 \mathrm{~m}$ gát & 1 & $0,5 \%$ \\
\hline 3000m akadály & 0 & $0 \%$ \\
\hline magasugrás & 12 & $6 \%$ \\
\hline távolugrás & 14 & $7 \%$ \\
\hline hármasugrás & 9 & $4,5 \%$ \\
\hline rúdugrás & 6 & $3 \%$ \\
\hline súlylökés & 20 & $10,1 \%$ \\
\hline gerelyhajítás & 14 & $7 \%$ \\
\hline diszkoszvetés & 14 & $7 \%$ \\
\hline kalapácsvetés & 6 & $3 \%$ \\
\hline többpróba & 6 & I $\quad 3 \%$ \\
\hline gyaloglás & 2 & $1 \%$ \\
\hline összes válasz & 199 & $100 \%$ \\
\hline
\end{tabular}




\section{Sportpályafutás kezdete}

A magyar szenior atléták jelentős része tizenévesként kezdte el a sportot (69,4\%). Tízéves kor előtt csak 7 fö (10,9\%), egy-egy válaszadó pedig csak a húszas-harmincas éveiben.

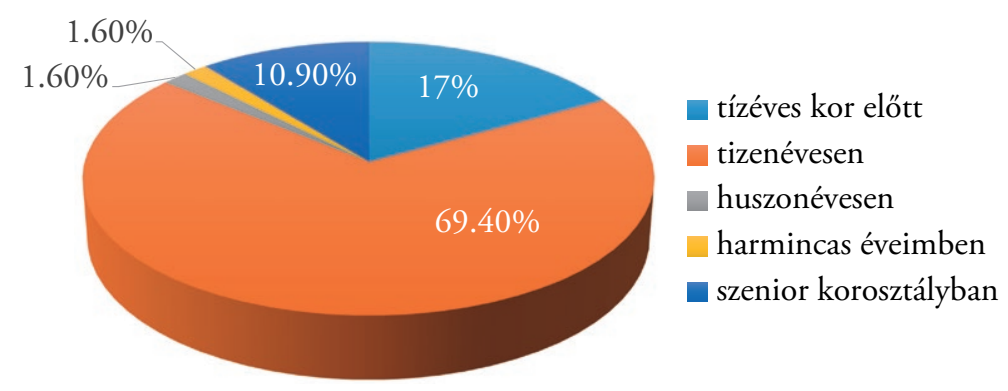

1. ábra A magyar szenior atléták ( $\mathrm{n}=65)$ atléta pályafutásának kezdete

\section{Újrakezdés}

Master atlétáink ötöde soha nem hagyta abba, vagy csak kisebb kihagyásokat iktatott atlétika pályafutásába. Fiatalkor után egyesek befejezték aktív atléta pályafutásukat. Azok, akik több mint öt éve kezdték újra 40\%-os arányt mutatnak, míg
$11 \%$ aktív 3-5 éve. Ez azt jelenti, hogy a válaszolók 76\%-a edz évek óta a szenior korosztályban, 8\%-a kezdte csak nemrég a veterán atlétikát, tehát bővül a szenior család. Az egyéb választ jelölők között 1 személy van, aki nem edz rendszeresen, csak versenyez, de sajnálja ezt az állapotot.

2. táblázat A magyar szenior atléták újrakezdésének ideje 2016-hoz viszonyítva ( $\mathrm{n}=65$ )

\begin{tabular}{|c|c|c|}
\hline soha nem hagytam abba & 13 & $20 \%$ \\
\hline több mint 5 éve & 25 & $38,5 \%$ \\
\hline 3-5 éve & 11 & $16,9 \%$ \\
\hline $1-2$ éve & 8 & $12,3 \%$ \\
\hline egyéb & 8 & $12,3 \%$ \\
\hline összes válasz & 65 & \\
\hline
\end{tabular}

Egyéb válaszok - „7 hónapja”, „6 éve kezdtem, előtte nem atletizáltam”, „26 évesen kezdtem azóta csinálom”, „Családalapítás után évtizedek maradtak ki.”, „Soha nem hagytam abba!”, „Sajnos csak a versenyeken indulok, atlétika edzésekre nem járok”, „Két és fél éve kezdtem el.”

\section{Az újrakezdés okai}

A többségnek a versenyzés a motivációja. Bár szabadidős tevékenységnek is megfelel az atlétika, remekül kielégíti a sportolni vágyók mozgásigényét. Nagy szerepet játszott az újrakezdésben a 2010es nyíregyházi Szabadtéri Európa-bajnokság és a 2014-es budapesti Fedettpályás Világbajnokság. Mivel a versenyzés minden költségét (utazás, szállás, nevezési díj, felszerelés) az atléták állják, a hazai rendezés nagy terhet vesz le a versenyezni vágyók válláról. Sokan gondolták úgy, hogy a magyarországi világversenyen indulás lehetősége elég erős motiváció az újrakezdéshez.

3. táblázat A magyar szenior atléták újrakezdésének okai (Mi motiválta az újrakezdésre?) ( $\mathrm{n}=65$ )

\begin{tabular}{|c|c|c|}
\hline $\begin{array}{c}\text { az egészségem megőrzése érdekében - } \\
\text { orvosi tanácsra }\end{array}$ & 2 & I,1\% \\
\hline szabadidős sportként & 6 & $9,2 \%$ \\
\hline hiányzott a mozgás & 13 & $20 \%$ \\
\hline versenyezni akartam & 36 & $55,4 \%$ \\
\hline
\end{tabular}




\begin{tabular}{|c|c|c|}
\hline egyéb & 8 & $12,3 \%$ \\
\hline összes válasz & 65 & \\
\hline
\end{tabular}

Egyéb válaszokhoz több, rövidebb-hosszabb válasz érkezett: „sportszeretet”, „párom hatására, aki szintén szenior atléta”, „nem kezdtem újra”, „nem újrakezdtem, hanem elkezdtem”, „soha nem hagytam abba!”, „barátaim rábeszélése”, „Gyerekkori edzőtársak inspiráltak és egy új ágát ismerhettem meg és lehettem benne eredményes Etédi Endre edzőmnek köszönhetően! Sajnos a kerületemben az Ikarusz S. E. tavasz óta ellehetetlenítette nekem a rúdugrást (havi 5000-ről 15000-re emelte a díjat), a Magyar Atlétikai Szövetség se segít minket.", „korábban nem sportoltam semmit”.

Szenior atléták szenior kor elötti sportolási szokásai

A legtöbben $(66,2 \%)$ fiatal korukban is atletizáltak. Négyen űztek valamilyen labdajátékot $(6,2 \%)$, 14-en egyéni sportágat műveltek, és négy válaszadó nem sportolt semmit.

4. táblázat A magyar szenior atléták szenior kor előtti sportolási szokásai (Szenior korod előtt milyen sportágat űztél?) ( $\mathrm{n}=65)$

\begin{tabular}{|c|c|c|}
\hline atlétika & 43 & $66,2 \%$ \\
\hline labdajáték & 4 & $6,2 \%$ \\
\hline úszás & 0 & $0 \%$ \\
\hline kerékpár & 2 & $3,1 \%$ \\
\hline szertorna & 1 & $1,5 \%$ \\
\hline nem sportoltam & 4 & $6,2 \%$ \\
\hline egyéb & 11 & $16,9 \%$ \\
\hline összes válasz & 65 & \\
\hline
\end{tabular}

Egyéb válaszok - „autósport”, „aerobik”, „tájékozódási futás”, „futás, foci, kondizás”, „taekwondo”, „néptánc, ha az sport”, „súlyemelés, testépítés”, „sok mindent”, és a teniszt 3-an is megjelölték.

\section{Eredményesség - fiatalkori eredményesség}

A fiatalkori eredményesség mutatója lehet a későbbi években folytatott sporttevékenységnek. A válasza adók igen magas arányban értek el országos szinten kiemelkedő eredményeket (67,7\%). A világversenyeken mutatott eredményesség azonban alacsonyak mondható (EB 1-8. hely 1,5\%, VB 1-8. hely nem volt).

Ebből arra következtethetünk, hogy elsősorban olyanok atletizálnak még 35 éves kor felett is, akik nem égtek ki a világviszonylatban is komoly eredmények eléréséhez szükséges igen magas megterhelés következtében, és/vagy tiltott szerek alkalmazása miatt. Ez fontos megállapítás, azonban további kutatást igényel. A téma érzékenysége miatt azonban nehezen kutatható.

5. táblázat A magyar szenior atléták fiatalkori eredményessége atlétikában (Mi a legjobb fiatalkori eredményed atlétikában?) ( $\mathrm{n}=65)$

\begin{tabular}{|c|c|c|}
\hline OB 1-8. hely & 44 & $67,7 \%$ \\
\hline EB 1-8. hely & 1 & $1,5 \%$ \\
\hline VB 1-8. hely & 0 & $0 \%$ \\
\hline nincs & 12 & $18,5 \%$ \\
\hline egyéb & 8 & $12,3 \%$ \\
\hline összes válasz & 65 & \\
\hline
\end{tabular}


Az egyéb válaszok változatosak - „megyei 2 . hely”, „megyei 1. hely”, „ifi 3. hely”, „középiskolában mezei futóverseny arany”, „felnőtt II. osztály, hétpróba”, „OB 12. hely”, „ezüstjelvényes sportoló”, „ifi OCSB 1. hely”.

\section{A magyar szenior atléták eredményessége}

Fiatal korban a válaszadók 18,5, szenior korban 6,2\%-a nem versenyzett eredményesen, nem ért el említésre méltó eredményt. EB és VB döntő szempontjából is jelentős különbség mutatkozik a szenior kor javára. Ezek szerint szenior atlétáink magasabb szinteken, többen érnek el kiemelkedő szintű eredményt, mint ahogyan azt ifjú korukban tették. EB döntő aránya: 1 fiatal/10 szenior, $V B$ döntő: 0 fiatal/24 szenior. Az OB eredményességének szempontjából viszont megállapítható, hogy a szenior kori eredményességnek közel duplája a fiatal kori eredményesség - 38,5\%/67,7\%.

Ezt az eredményt több összetevő határozza meg, ami szintén további kutatásokat igényel. Szenior korban a világversenyeken feltételezhetően kevesebben élnek tiltott szerekkel, azért az edzésmunka szerepe nőhet, a mezőny kiegyenlítettebb, a munka és a szorgalom, tehetség arányának szerepe pozitív irányba mozdul. A válogatási rendszer az egyes nemzeteknél az állami és szponzori támogatottságtól függhet. Szenior korban nincs válogatási rend, csak a saját akarat, motiváció és az önfinanszírozás. $\mathrm{Az}$ atlétika támogatottsága Magyarországon arányaiban jelentősen alacsonyabb, mint más nemzeteknél, a szenior atlétika pedig zéró támogatottságú. Ennek megfelelően, ebben a korban nagyobb részben juthatnak lehetőséghez az arányaiban jobban felkészült atléták, ami az eredményességükön is látszik. Ezek a törekvések alkalmasint annyira erősek, hogy a saját szövetség által állított akadályok, ill. elutasító magatartás ellenére is megtalálják az utat a kiemelkedő eredmények felé, amit összefoglalva teljesítőképes akaratnak is nevezhetnénk.

6. táblázat A magyar szenior atléták szenior kori eredményessége (Mi a legjobb szenior kori eredményed?) $(\mathrm{n}=65)$

\begin{tabular}{|c|c|c|}
\hline OB 1-8 hely & 25 & $38,5 \%$ \\
\hline EB 1-8 hely & 10 & $15,4 \%$ \\
\hline VB 1-8 hely & 24 & $36,9 \%$ \\
\hline nincs & 4 & $6,2 \%$ \\
\hline egyéb & 2 & $3,1 \%$ \\
\hline összes válasz & 65 & \\
\hline
\end{tabular}

Az egyéb válaszok között a „sok jó eredményem van" némileg szórakozott hozzáállást mutat, az „Európa Szenior Játékok 2. hely” viszont komolyabb teljesítményre utal, lévén azok a versenyek is komoly felkészültséget feltételeznek.

\section{Az edzö személye}

A magyar szenior atléták fiatal kori edzője elsősorban (67,7\%-os arányban) egyesületi edző volt, valamint a testnevelö $(23,1 \%)$ mellett az önedzés jelenik még meg a válaszok között (7,7\%).

7. táblázat A magyar szenior atléták edzőjének személye fiatal korban (Fiatalkori sportolásodat ki irányította?) $(n=65)$

\begin{tabular}{|c|c|c|}
\hline egyesületi edző & 44 & $67,7 \%$ \\
\hline testnevelő & 15 & $23,1 \%$ \\
\hline barát, ismerős & 0 & $0 \%$ \\
\hline magam & 5 & $7,7 \%$ \\
\hline egyéb & 1 & $1,5 \%$ \\
\hline összes válasz & 65 & \\
\hline
\end{tabular}


Az egyéb válaszokat a nem sportolók adták.

Míg fiatal korban a nagy többség $(90,8 \%)$ sportolt szervezett keretek között, azaz testnevelő vagy edző irányításával, addig a szeniorokra inkább jellemző, hogy önmaguk edzői, vagy ismerősük, barátjuk az irányadó. Ez nem feltétlenül jó annak ellenére, hogy a sokévi edzés alatt megismerték a testük működését, a korábban megtanult edzésmódszereket alkalmazzák.

A veterán atlétákra nem jellemző a szakági edzői irányítás, az egyesületeknek sem füződik semmilyen érdeke ennek megszervezésére, bár ez az eredményesség szempontjából hátrányos. A munka és család mellet nem könnyü az edzések, felmérések szervezése. A kérdőívből kiderül, hogy az edzéslehetőségek akadályozására is van példa, pedig még neves szakedzővel is rendelkezik a klub. Az eredmények még inkább rávilágítanak arra, hogy a szenior atlétikában eredményesség szempontjából még bőven van potenciál, ha az edző kérdés megoldódik, vagy legalább javul. A válaszok alapján arra biztatnánk a szenior atlétákat, hogy csatlakozzanak más korosztályok edzés csoportjaihoz, keressék az egyesületi edzőkkel a kapcsolatot és igyekezzenek megoldani az edző problémáját, legalább konzultáció szintjén, de még szerencsésebb, ha teljes irányítottságú módon.

Elvitathatatlan az edző által kontrolált edzésmunka szerepe a teljesítményben! A magyar atléta edzőknek pedig kitűnő alkalom lenne, hogy tisztába kerüljenek a 35 feletti korosztály edzésén keresztül a korosztály edzésélettanával, ill. a regeneráció szerepének fontosságával a fiatalabb korosztályokban.

8. táblázat A magyar szenior atléták edzőjének személye (Szenior kori sportolásodat ki irányítja?) ( $\mathrm{n}=65$ )

\begin{tabular}{|c|c|c|}
\hline egyesületi edző & 17 & $26,2 \%$ \\
\hline testnevelő & 0 & $0 \%$ \\
\hline barát, ismerős & 5 & $7,7 \%$ \\
\hline saját magam & 41 & $63,1 \%$ \\
\hline egyéb & 2 & $3,1 \%$ \\
\hline összes válasz & 65 & \\
\hline
\end{tabular}

Egyéb válaszok között a „fiatalkori edzőm, sporttársam”, „én és a barátom”.

\section{Edzésgyakoriság}

Az edzésgyakoriságra adott válaszok elsősorban a fiatal/felnőtt atléták elhivatottságának mutatója. Az 5-6, ill. 7 vagy annál gyakoribb edzés per hét válasz meghatározó motivációs háttérről árulkodik. Ezek aránya a összes válaszadóhoz képest 63\%-os, ami jelentősnek mondható.

A szenior korban az 5-6, ill. 7 vagy több edzés per hét az összes válasz 30\%-a, hiszen az egyéb válaszok között megjelenik egy 6-7 szám, ami ebbe a kategóriába tartozik, azaz az elemszám így már $\mathrm{n}=20$.

Az edzésgyakoriság pontos mutatója lehet az eredményességnek, a jól felépített edzések és a megfelelő regeneráció mellett. Az edzések száma eltolódik, csökken a szenior versenyzőknél, a fiatalkori 7 és több helyett inkább csak heti 5-6 edzést végeznek. A korábbi 5-6 alkalom helyett 3-4-szer sportolnak. A kérdőívben nem jelenik meg, és külön hasznos kapcsolatokat mutatna az edzés gyakoriság és a teljesítmény, valamint az eredményesség összefüggés vizsgálata az egyes korosztályoknál.

9. táblázat Hányszor edzettél egy héten fiatal korodban (Hányszor edzettél egy héten fiatal ill. szenior korodban?) $(\mathrm{n}=65+65)$

\begin{tabular}{|c|c|c|c|}
\hline \multirow{2}{*}{ heti 1-2 alkalom } & fiatal & 7 & $10.8 \%$ \\
\cline { 2 - 4 } & szenior & 15 & $23.1 \%$ \\
\hline
\end{tabular}




\begin{tabular}{|c|c|c|c|}
\hline \multirow{2}{*}{ heti 3-4 alkalom } & fiatal & 14 & $21.5 \%$ \\
\cline { 2 - 5 } & szenior & 27 & $41.5 \%$ \\
\hline \multirow{2}{*}{ heti 5-6 alkalom } & fiatal & 28 & $43.1 \%$ \\
\cline { 2 - 5 } & szenior & 18 & $27.7 \%$ \\
\hline \multirow{2}{*}{ heti 7 vagy gyakrabban } & fiatal & 13 & $20 \%$ \\
\cline { 2 - 5 } & szenior & 1 & $1.5 \%$ \\
\hline \multirow{2}{*}{ egyéb } & fiatal & 3 & $4.6 \%$ \\
\cline { 2 - 5 } & szenior & 4 & $6.2 \%$ \\
\hline összes válasz & & $65+65$ & \\
\hline
\end{tabular}

Egyéb válaszok fiatal/felnőtt atléták: „havonta 1-2-szer”, „nem edzettem”; szenior atléták: „6-7”, „4-5”, „2-3 alkalommal”.

\section{Edzéskörülmények}

Fiatal korban a többség (60\%) salakpályán edzett, és rekortánon csak 13,8\% (9 fó). Ma már a műanyag pályák elterjedésének (Budapesten 10, ill. sok vidéki városban is műanyag pálya van) köszönhetően 41,5\%-a a szenior atlétáknak (27fó) edz rendszeresen műanyag pályán. Az eredményt torzítja azonban, hogy 28 fó fóvárosi lakos található a kitöltők között. Az eredményesség szempontjából meghatározó fontosságú az optimális edzéskörülmény: a szenior világversenyen döntőbe jutott versenyzők (35 fö - 55,4\%) megfelelő körülmények között tud készülni. Azonban sokaknak nincs lehetőségük rendszeresen jó körülmények között edzeni a mai napig sem.

10. táblázat Milyen körülmények között edzettél fiatal, ill. szenior korodban (Milyen körülmények között edzettél fiatal korodban?) $\quad(n=65+65)$

\begin{tabular}{|c|c|c|c|}
\hline \multirow{2}{*}{ mủanyag pályán, jól felszerelt erősítőteremben } & fiatal & 9 & $13,8 \%$ \\
\cline { 2 - 4 } & szenior & 27 & $41,5 \%$ \\
\hline \multirow{2}{*}{ salak atlétika pályán, erősítő teremben } & fiatal & 39 & $60 \%$ \\
\cline { 2 - 4 } & szenior & 12 & $18,5 \%$ \\
\hline \multirow{2}{*}{ Nyáron, iskolaudvaron, télen tornateremben } & fiatal & 10 & $15,4 \%$ \\
\cline { 2 - 4 } & szenior & 4 & $6,2 \%$ \\
\hline \multirow{2}{*}{ szabadban: erdő, park, stb. } & fiatal & 4 & $6,2 \%$ \\
\cline { 2 - 4 } & szenior & 13 & $20 \%$ \\
\hline \multirow{2}{*}{ egyéb } & fiatal & 3 & $4,6 \%$ \\
\cline { 2 - 4 } & szenior & 9 & $13,8 \%$ \\
\hline összes válasz & & $65+65$ & \\
\hline
\end{tabular}

Az egyéb válaszok között megjelenik még a legkézenfekvőbb, szinte minden településen megtalálható „füves focipálya”, a „semmi”, ill. a „lakás”, valamint a „versenyek".

Az egyéb válaszok hasonlóak voltak a fiatal kori edzéslehetőségekhez. A beírt egyéb lehetőségek között többen jelölték meg az „országutat”, de voltak, akik nem tudtak válaszolni egyértelmüen és így a „mikor, hol”, az „ahol éppen lehetőség van”, „nincs dobópályánk”, vagy a „rekortán, gyakrabban 
aszfalt”, de a „lakás”, „versenyek”, „utca” is szerepelt az egyéb válasz lehetőségek között.

A szenior atléták éves versenyzéssel kapcsolatos költségei

Mivel teljesen amatőrök, tehát önmaguk által finanszírozott a sporttevékenységük, képet kaphatunk arról, hogy mire költenek és milyen nagyságrendben a veterán atléták.

Cipőre, ruhára éves szinten 27 fö költ többet, mint $30.000 \mathrm{Ft}$, de 1 fó $90.000 \mathrm{Ft}$-nál is többet. Speciális cipőre 14-en költenek 20.000 Ft felett. A sportorvosi vizsgálatok, költségek szükséges velejárói a komoly spottevékenységnek. A tagdíjak az egyesülethez tartozást jelentik, havi 1000 és 5000 Ft közötti összegben. 1 fö éves szinten 90.000
Ft-nál is többet fizet. Utazásra, szállásra valamint nevezési díjra a szomszédos országok bajnokságain és a világversenyen indulók adnak ki legtöbbet, de emeli a költségeket, ha gyúró is utazik a versenyzőkkel. Regenerációra (gyúrás, szauna) és táplálékkiegészítőkre szintén komoly összegeket költenek a szenior atléták, különösen a magasabb célokat kitűzők.

A válaszokból érzékelhető, hogy a sportgazdasághoz egyre nagyobb arányban hozzájáruló rétegről van itt szó.

Az éves költségek táblázatokban nem jelenítjük meg azokat a költség sávokat, amelyekre 0 megjelölés érkezett.

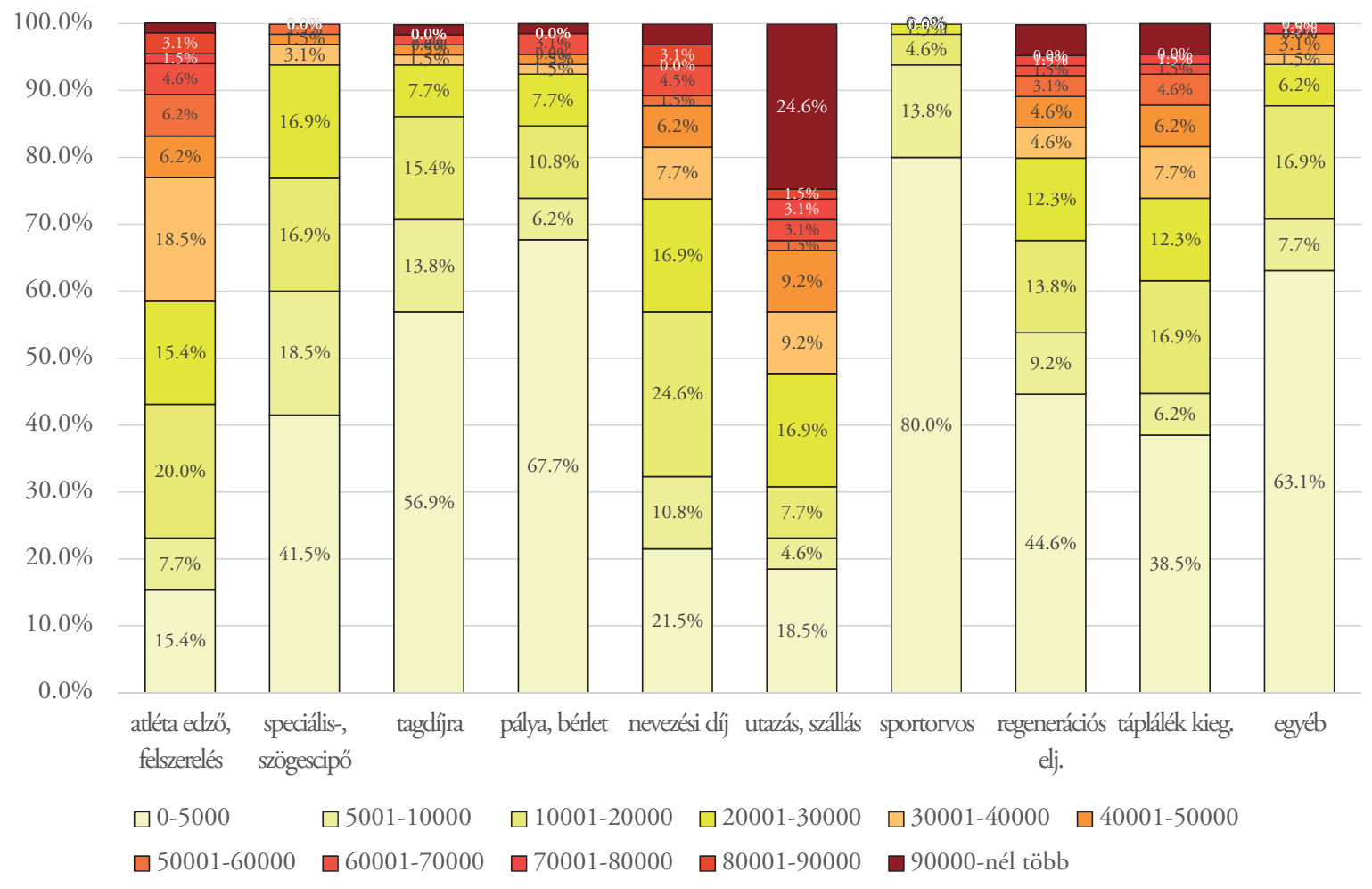

2. ábra A szenior atléták éves versenyzéssel kapcsolatos költségei

\section{Szenior atléták erkölcsi támogatottsága}

A kérdőív kitöltői a legnagyobb (időnkénti és maximális) támogatást a szenior atlétáktól kapják (azaz saját közösségtől): 46 fö (70,7\%). Ezt követi az egyesület $(41,5 \%)$, a szakosztály $(30,8 \%)$ és a munkahely (29,3\%).

A Magyar Atlétika Szövetségről mindösszesen 3 fö $(4,6 \%)$ nyilatkozta, hogy időnként támogatja. A munkahelyi támogatás a legmagasabb, és itt senkit sem ér hátrány a sport miatt. Sajnálatos módon a MASZ-ról érkezett a legtöbb 12 fö (18,5\%) negatív vélemény, miszerint „inkább akadályoznak” illetve semennyi erkölcsi támogatást 50 fö $(76,9 \%)$ nem nyújtanak. Ebből arra következtetünk, hogy saját sportági szövetsége által teljes mértékben elhanyagoltnak érzi magát a szenior atlétika, ami komoly gondok forrása és teljesen ellentétes sok európai nagy nemzet szövetségének hozzáállásával. Ezen a közeljövőben drasztikusan és nagylelkűen kell változtatnia az említett szervezetnek! 


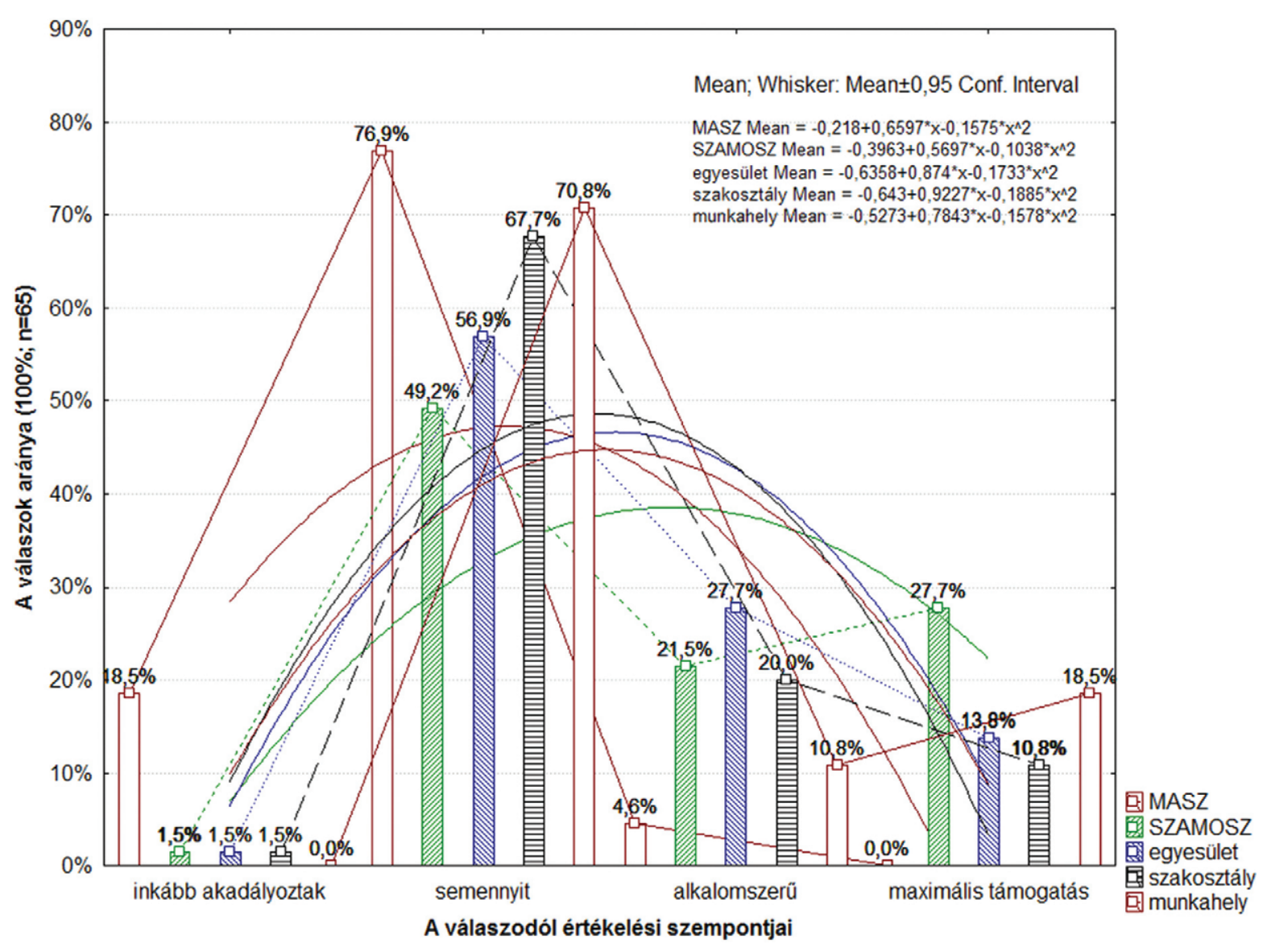

3. ábra A magyar szenior atléták erkölcsi támogatottsága. (Mekkora erkölcsi támogatást kapsz az alábbi szervezetektől?) $(\mathrm{n}=65)$

\section{Diszkusszió}

Jelen tanulmánnyal fó célunk volt közelebbi képet adni az atlétika sportágat idősebb korban is űzők pillanatnyi állapotáról, a hátteréről és jelenlegi helyzetéről. A dolgozat időszerűségét az elmúlt évek és az idei világversenyek eredményessége támasztja alá, külön kiemelve, hogy az összes VB, EB siker önerőből, központi támogatás nélkül született.

A kérdőíves módszerrel 65 magyar szenior atlétát szólítottunk meg, a fiatal és szenior kori edzési szokásaikat, körülményeiket vizsgálva. A fö szempont az eredményesség volt, mellyel összefüggésben vizsgáltam a többi kérdésre adott választ. A legerősebb motiváció is az eredményességgel függ össze, hiszen a válaszadók többsége a versenyzés miatt kezdte újra a sportolást. Ennek tükrében a válaszok alapján, a következő eredmények születtek.

A szenior atléták 70\%-a tizenévesen kezdte az atlétikát, majd több mint 20\%-uk sohasem hagyta abba a sportolást. A szenior atléták 66\%-a atletizált fiatal korában is, 6\% nem sportolt semmit, 16\% valamilyen más mozgásformát gyakorolt, például néptáncolt, teniszezett, vagy az autósportban volt járatos. A legnépszerűbb versenyszámok a $100 \mathrm{~m}$ futás és a súlylökés.

Csak kevesek edzésmunkáját irányítja egyesületi edző, a többség önmaga edzője, mely eredmények összecsengenek Béresés mtsi. (2011) által leírtakkal. Az eredményesség egyik összetevőjében, a heti edzés gyakoriságban is van eltérés a fiatalkori szokásokhoz képest, de akad olyan atléta is, aki nem nagyon edz, csak versenyeken indul. A szenior kori edzéskörülmények vizsgálata azt mutatja, hogy ma már a többség mủanyag pályán végzi az edzéseit, kevesebben salakon. Vannak, akik csak alkalomszerüen edzenek ott, ahol éppen lehetősége adódik.

Az éves költségek eloszlásának vizsgálata alapján a sportgazdasághoz egyre nagyobb arányban hozzájáruló rétegről van szó.

A szenior atléták nagy többségének az eredményes versenyzés a motivációja, s életmódjának 
szerves részévé vált a jól felépített felkészülés a következő szezon hazai és nemzetközi versenyeire.

Időskori sportolásként atlétikát csak kevesen választanak egészség megőrzési céllal, ill. nem ez a fö motivációja.

Az edzés gyakoriság mutatója összefüggést mutat az eredményességgel. Még ebben a korosztályban is igaz, hogy a jó eredményhez többet kell dolgozni. Az edzéskörülmények sokat javultak a fiatalkori lehetőségekhez képest. Az atléták többsége jó körülmények között tud készülni, ami megmutatkozik az eredményekben is.

Az edző személye nincs összefüggésben az eredményességgel ebben a korosztályban, hiszen csak keveseknek a felkészülését irányítja egyesületi edző - feltételezzük, hogy magasabb szintű edzői jelenlét még jobb teljesítményeket eredményezhetne, de ez egy újabb kutatás témáját képezi.

Eredményesség tekintetében szenior korban is fontos a minőségi háttér, a megfelelő számú edzés, de a magas szintü motiváció, az erkölcsi támogatás a legszükségesebb.

Összességében elmondhatjuk, hogy a szövetség támogatását abszolút nem élvező szenior atlétika ma Magyarországon, - teljes mértékben amatőr státuszával -, a nemzetközi élvonalban az önfinanszírozás mellett is jelentősen jobb eredményeket ér el, mint bármely más korosztály.

Dolgozatunk megírásával szerettünk volna képet festeni a magyar és a nemzetközi szenior atlétikáról, valamint olyan adatokkal szolgálni a sportolók és sportvezetőség felé, amely több kérdést megválaszolva lehet segítségére a felnőtt és szenior atlétikának. Bízunk abban, hogy e sport irányításának ellenállása hamarosan megenyhül és a szó szoros és átvitt értelmében is felnőtt módjára viselkednek és bánnak majd szeniorjaikkal.

\section{Irodalomjegyzék}

1. Bakonyi F., Nádori L. (1980): Az állóképesség életkori szintjei 4 - 12 éves korban. A sport és testnevelés idöszerü kérdései, 22. 5-37.

2. Béres S., László A., Hámori Zs., Tóth J. (2011): A szenior atlétika Magyarországon. Recreacio.eu 09.I.2.-3. 34-36.
3. Csider T., Fábián Gy. (1984): Csoportlélektani tényezők befolyása a Cooper-teszt teljesítményére Testnevelés és Sporttudomány 3. 22-24.

4. Hajnal, K. (2005): Az öregedés biológiája. PTE TTK Genetikai és Molekuláris Biológiai Tanszék

5. Polgár T., Béres S. (2011): Az atlétika története, technikája, oktatása, szabályai. Dialóg Campus Kiadó, Budapest, 600p (?)

6. Stephard, R. J.(1998): Aging and exercise. (Az öregedés és az edzés.) Internet Society for Sport Science (http:// sportsic.org)

7. Rehpenning, B., Harvey R., Beckers S. (2010): Age factors table - combined events - men/women. WMA Modell 2010 (http:// www.results-model2010.de/WMA_ MODEL_2010_F.pdf)

\section{Internetes irodalmak:}

8. WMA, World Masters Athletics Assosiation (Nemzetközi Maszter Szövetség) szabálykönyve - https://www.world-masters-athletics.org/ rules.htm

9. SZAMOSZ (Szenior Atléták Magyarországi Szövetsége) Müködési szabályzat. Honlap: www.szamosz.hu

10. World Masters Rankings - gyüjti és feldolgozza a szenior atlétika versenyek eredményeit, világ- és regionális ranglistákat állít össze. Felhívja a figyelmet a közelgő világversenyekre, aktuális kérdésekről ad információt. - https:// www.mastersrankings.com

11. MASZ (Magyar Atlétika Szövetség) Szenior Bizottsága. - https://atletika.hu

12. Masters athletics - https://en.wikipedia.org/ wiki/Masters_athletics (2017.01.27.)

13. Turcziné S. É. (2014): További veterán sikerek: Ajkler aranya és Kurunczi világcsúcsa. http:// edzesonline.hu - Bozót - (2014)

14. Juha P. (2014): Fut, ugrik, hajit a 95 éves szupernagyi.http://www.origo.hu/sport/ egyeb/atletika/20140325-budapesten-a95-eves-csodano-beszelgetes-olga-kotelkoveteran-atletanovel.html - Juha Pál - (2014) 